\title{
SOME OBSERVATIONS ON THE REPERTORY OF TROPES AT ST EMMERAM, REGENSBURG
}

\author{
I
}

The changing repertory in the early manuscripts

The three early sources which can confidently be assigned to the monastery of St Emmeram at Regensburg - Bamberg Staatsbibliothek lit.6, Munich Bayerische Staatsbibliothek clm 14083 and 14322 - have by no means identical trope repertories. The provenance of the manuscripts is hardly contestable. Bamberg 6 was probably written in the closing years of the 10th century. If Bischoff is correct, ${ }^{1} \mathrm{clm} 14083$ belongs to the reign of abbot Burkhard, 1031-7, while clm 14322 is slightly more recent. If these manuscripts contain all the tropes that were sung at the time of their compilation, then the St Emmeram repertory must have been revised from time to time, twice within half a century, in fact.

The tropes in Bamberg 6 do not extend over the whole year but only as far as Easter. Additional pieces were then entered for Easter itself, for Ascension and the Nativity of the Virgin. There are only Introit tropes. In clm 14083 there has been a fairly systematic attempt to provide for all the main feasts of the church year, and the highest feasts have offertory and communion tropes as well. Clm 14322 recognizes practically as many occasions as clm 14083 , but has fewer tropes for them, with only one offertory set and one communion set, in circumstances which make them look like oversights. Table I displays the provision made in each of the three sources.

\footnotetext{
1 Bernhard Bischoff, "Literarisches und künstlerisches Leben in St.Emmeram (Regensburg) während des frühen und hohen Mittelalters", Studien und Mitteilungen zur Geschichte des Benediktiner-Ordens und seiner Zweige 51 (1933), 102-142; revised version in Bischoff, Mittelalterliche Studien 2 (Stuttgart, 1967), 77-115. See esp. Studien und Mitteilungen, 112-113, Mittelalterliche Studien, 87. Summary information is given by Heinrich Husmann, Tropen- und Sequenzenhandschriften, RISM B/V/1 (München-Duisburg, 1964), 74-78. On Bamberg 6 see the recent study, including a complete inventory, by Günther Michael Paucker, Das Graduale Msc. Lit. 6 der Staatsbibliothek Bamberg. Eine Handschriften-Monographie unter besonderer Berucksichtigung des Repertoires und der Notation, Forschungsbeiträge zur Musikwissenschaft 30 (Regensburg, 1986).
} 
TABLE 1

PROVISION OF TROPES

\begin{tabular}{|c|c|c|c|c|}
\hline Feast & Chant & $\begin{array}{l}\text { Bamberg } \\
6\end{array}$ & $\begin{array}{l}\mathrm{clm} \\
14083\end{array}$ & $\begin{array}{l}\text { clm } \\
14322\end{array}$ \\
\hline Christmas & $\begin{array}{l}\text { Int } \\
\text { Off } \\
\text { Com }\end{array}$ & $x$ & $\begin{array}{l}x \\
x \\
x\end{array}$ & $\mathbf{x}$ \\
\hline Stephen & $\begin{array}{l}\text { Int } \\
\text { Off } \\
\text { Com }\end{array}$ & $\mathbf{x}$ & $\begin{array}{l}\mathbf{x} \\
\mathbf{x} \\
\mathbf{x}\end{array}$ & $\mathbf{x}$ \\
\hline John Evangelist & $\begin{array}{l}\text { Int } \\
\text { Off } \\
\text { Com }\end{array}$ & $x$ & $\begin{array}{l}x \\
x \\
x\end{array}$ & $\mathbf{x}$ \\
\hline Innocents & $\begin{array}{l}\text { Int } \\
\text { Off } \\
\text { Com }\end{array}$ & & $\begin{array}{l}\mathbf{x} \\
\mathbf{x} \\
\mathbf{x}\end{array}$ & $\mathbf{x}$ \\
\hline Octave ND & Int & & $x$ & $x$ \\
\hline Epiphany & $\begin{array}{l}\text { Int } \\
\text { Off } \\
\text { Com }\end{array}$ & $x$ & $\begin{array}{l}\mathbf{x} \\
\mathbf{x} \\
\mathbf{x}\end{array}$ & $\mathbf{x}$ \\
\hline Purification & $\begin{array}{l}\text { Int } \\
\text { Off } \\
\text { Com }\end{array}$ & $\mathbf{x}$ & $\begin{array}{l}\mathbf{x} \\
\mathbf{x} \\
\mathbf{x}\end{array}$ & $\mathbf{x}$ \\
\hline Easter & $\begin{array}{l}\text { Int } \\
\text { Off } \\
\text { Com }\end{array}$ & $\mathbf{x}$ & $\begin{array}{l}\mathbf{x} \\
\mathbf{x} \\
\mathbf{x}\end{array}$ & $\mathbf{x}$ \\
\hline Wednesday & Int & & $x$ & \\
\hline Octave Easter & $\begin{array}{l}\text { Int } \\
\text { Com }\end{array}$ & & $\begin{array}{l}\mathbf{x} \\
\mathbf{x}\end{array}$ & \\
\hline Ascension & Int & ad & $\mathbf{x}$ & $x$ \\
\hline Pentecost & $\begin{array}{l}\text { Int } \\
\text { Off } \\
\text { Com }\end{array}$ & & $\begin{array}{l}x \\
x \\
x\end{array}$ & $\mathbf{x}$ \\
\hline John Baptist & $\begin{array}{l}\text { Int } \\
\text { Off } \\
\text { Com }\end{array}$ & & $\begin{array}{l}\mathbf{x} \\
\mathbf{x} \\
\mathbf{x}\end{array}$ & $\mathbf{x}$ \\
\hline Peter \& Paul & Int & & $\mathbf{x}$ & $\mathbf{x}$ \\
\hline Benedict & Int & & $\mathrm{x}$ & $\mathbf{x}$ \\
\hline
\end{tabular}


Laurence

Assumption BVM

Int

X

Nativity BVM

Int

ad

$\mathbf{x}$

Int

$\mathbf{x}$

Emmeram

Int

$\mathrm{x} \quad \mathrm{x}$

Michael

Int

$\mathrm{x}$

$\mathbf{x}$

Martin

Int

Int

$\mathbf{x}$

$$
\mathbf{x}
$$

Andrew

Int

Apostles

Martyrs

Int

Off

$\mathbf{x}$

$$
\text { x }
$$

X

x

$\mathbf{x}$

Martyr

Int

$\mathbf{x}$

Confessor

Int

$\mathbf{x}$

Virgin

Int

x

Dedication

Int

Com

The Laudes regiae in clm 14322 originally contained the name of Conrad II as 'king' (1024-7; emperor 1027-39), later erased. If Bischoff is right in dating the manuscript to the 1040s, then the names in the Laudes regiae were taken over mechanically from an older exemplar and erased when discovered to be inappropriate. The question of the date is important for the tropes, because we have to choose between the order

or

$$
\begin{aligned}
& \text { Bamberg } 6 \text { (early repertory) }> \\
& \text { clm } 14322 \text { (modest provision) > } \\
& \text { clm } 14083 \text { (generous provision) }
\end{aligned}
$$

$$
\begin{aligned}
& \text { Bamberg } 6 \text { (early repertory) }> \\
& \text { clm } 14083 \text { (full provision) }> \\
& \text { clm } 14322 \text { (reduced provision) }
\end{aligned}
$$

I myself feel that Bischoff is correct, partly because on numerous occasions clm 14322 has less than Bamberg 6. Let us look at the provision for Epiphany, Purification and Easter, which follow each other in the three sources. Table 2 lists the trope verses for these feasts. 
TABLE 2 - TROPES FOR EPIPHANY, PURIFICATION AND EASTER

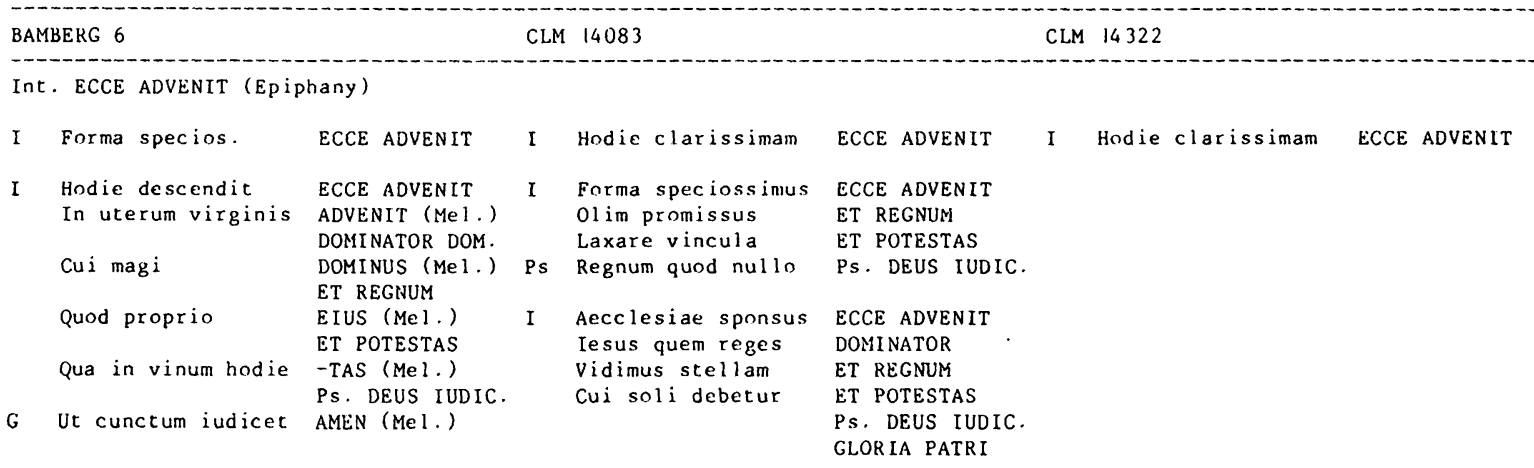

Off. REGES THARSIS (Epiphany)

O O redemptor omnium REGES THARSIS

Com. VIdimus STELlaM EIUS (Epiphany)

C Nato novo principe VIDIMUS STELLAM

Int. SUSCEPIMUS DEUS (Purification)

I Hodie quemadmodum SUSCEPIMUS

Omnipotens genitor MISERICORDIAM

Christum videlicet IN MEDIO

Quando parentes SECUNDUM NOMEN

Quod est magnificum ITA ET LAUS

Ab universa $1 N$ FINES TERRE

Hodie quenadmodum SUSCEPIMUS
Omnipotens genitor MISERICORDIAM

Christum videlicet IN MEDIO

Quando parentes SECUNDUM NOMEN

PS. MAGNUS DOM.

Qund est magnificum ITA ET LAUS

$A b$ universa $\quad$ IN FINES TERRE

I Qund in Iherusalem 〈SUSCEPIMUS> $G$ Qund in Therusalem DASUS DOM.

Off. DIFFusa EST GRATIA (Purification)

- Salve mater formosa DIFFUSA EST

ov Polle dei genitrix V. SPECIE TUA 
C Dum peteret votis RESPONSUM

Int. RESURREXI (Easter)

I Hodie resurrexit RESURREXI Perfractis ed prius ET ADHUC
Sedens a dextris Cum mortem subire MIRABILIS Quando filium ALLELUIA

I Hodie resurtexit RESURREXI

I Postquam factus

RESURREXI Postquam factus

Laudibus angelorum MIRABILIS

In regno superno POSUISTI

PS. DOMINE PR.

Cui canunt

ALLELUIA

PS. DOMINE PR.

I Postquam factus RESURREXI

I Postquam factus RESURREXI

Cui canunt ALLELUIA

ALLELUIA
Ps. DOHINE PR.

In regno superno POSUISTI

Laudibus angelorum MIRABILIS

Cui canunt ALLELUIA

(addition)

I Qui crucifixus eram RESURREXI

Trusi tartarea POSUISTI

Queque sub occulto MIRABILIS

Eia triumphantem ALLELUIA (last)

I Nos in laude ALLELUIA (first)

PS. DOHINE PR.

off. TERRA TREMUIt (Easter)

- Gaudete et cantate TERRA TREMUIT

Monumenta aperta DUM RESURGERET

Com. PASCHA NOSTRUM (Easter)

C In lege prisca PASCHA NOSTRUM

- trope verse for introit antiphon

- trope verse for psalm verse

- trope verse for Gloria patris

- trope verse for offertory

- trope verse for offertory verse

- trope verse for communion antiphon

Mel.

- melisma (extension of a phrase in the introit antiphon) 
For Epiphany Bamberg 6 has the introductory verse Forma speciossimus, then the set of verses Hodie descendit with melismatic extensions for the introit phrases. That type of troping, cultivated enthusiastically at St Gall but little elsewhere, was not welcome to the compiler of clm 14083. There is a different introduction, one of the 'Hodie' type, Hodie clarissimam, then sets of verses both for the introit, starting Forma speciossimus, and its repeat. There follow offertory and communion tropes. Clm 14322 has none of the Bamberg 6 tropes, only the introductory Hodie clarissimam. It could be argued that it was decided to replace the tropes in Bamberg 6 with Hodie clarissimam,

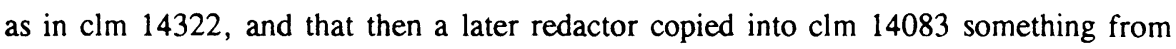
Bamberg 6, the new introduction in clm 14322 and more verses as well.

No doubt the same could be argued for the Purification tropes, where the pattern is even simpler.

For Easter there were two sets in Bamberg 6, Hodie resurrexit and Postquam factus. Later a third set was added, Qui crucifixus eram. Clm 14322 has only Postquam factus. Clm 14083 has Hodie resurrexit as a single introductory verse only, then the set Postquam factus. The set added in Bamberg 6, Qui crucifixus eram, is assigned to the Easter octave in clm 14083.

In all these cases (and of course others -- these are just selected for illustration) it seems simpler to argue that clm 14083 is earlier than clm 14322 and that prior to the compilation of clm 14322 a decision had been taken to reduce the amount of troping. I do not yet know why this should have been done, because at the same time clm 14322 has far more offertory prosulas than clm 14083. If some ecclesiastical reform had set its face against an overenthusiastic troping practice, why were the prosulas multiplied? The few offertory prosulas in clm 14083 appear amid the tropes. There are none in the offertory fascicle itself. In other words, their situation in the manuscript might suggest a certain insecurity of liturgical use. Perhaps clm 14322 attempts to balance things out between the various types of troping.

Support for the view that clm 14322 represents a later revision comes from manuscript clm 14845, of around 1120-25.2 This has much the same repertory as clm 14322. Thus for Epiphany it has only Hodie clarissimam, for Purification only Hodie quemadmodum. For Easter Hodie resurrexit dominus is given, but without notation, as if it were no longer actually sung; the set Postquam factus - In regno superbo Laudibus angelorum - Cuius canant follows, with notation.

\footnotetext{
${ }^{2}$ Husmann, op. cit. , 79-81.
} 


\section{Affiliations with other repertories}

Further comment about the mutual relationships between these sources, which would also have to include consideration of those from Seeon, linked to St Emmeram by monastic reform, ${ }^{3}$ must be postponed until a later occasion. I wish to turn now to the relationships between St Emmeram and the 'outside world', so to speak. For there are a number of striking concordances between the St Emmeram books and others from outside Southern Germany and Switzerland, even outside Germany altogether. This development affects chiefly manuscript clm 14083, as we should expect. The way its repertory was built up is very interesting, starting from the basis of something like Bamberg 6, introducing a few (very few) local items, some South German/Swiss ones, some internationally known ones. But there may also be evidence for contact with some centre or centres much further afield.

The sequence collection in clm 14083 is already symptomatic in this respect. Bamberg 6 has 51 sequences, practically all from the St Gall repertory. Clm 14083 has 72. Some of the new ones come from St Gall or that area, but a number come from the West: Nato canunt omnia (to provide all three Christmas masses with a sequence); Sancti merita Benedicti (a second sequence for Benedict, in a supplement at the end); Ave dei genitrix summe (a western melody) and Salve porta perpetue lucis (second and third sequences for the Assumption), Nunc crucis alme (without notation), Ad celebres (third sequence for Michael, in the supplement), Alma chorus domini (third Trinity sequence) and Stans a longe (for a summer Sunday).

It might be possible by comparing variant readings to decide whence these sequences came to St Emmeram.

Clm 14322 cuts back decidedly on all this, having only 38 sequences. Duplicates are cut out, only three days in Easter week have a sequence, there are none for the Sundays after Easter. Even the sequence for Benedict remains unnotated. There is only one new sequence: Otloh's composition for the discovery of the relics of St Dionysius.

Similarly, some of the tropes in clm 14083 are to be found outside the St Emmeram/Seeon circle only in books from the Rhine/Mosel area or further west. In two cases the only other sources are Western ones. Table 3 lists the items which appear to have come to St Emmeram from outside the South German/Swiss area.

\footnotetext{
${ }^{3}$ Seeon, south of the Inn near the Chiemsee, was reformed from St Emmeram and may have taken over elements of its liturgical practice. Trope sources certainly or probably from Seeon include Vienna Nationalbibliothek 1845 (mid-11th c.), Rome Biblioteca Angelica 948 (early-12th c.) and Kassel Murhardsche Bibliothek $4^{\circ}$ theol 15 (early-11th c.).
} 
TABLE 3 - TROPES FROM OUTSIDE SOUTH GERIAINY AND SWITZERLAND

\section{A. TROPES IN CENTRAL AND WESTERN SOURCES}

Com. EXIIT SERMO (John Evangelist)

Vita deus dum vult EXIT SERMO

Int. EX ORE INFANTIUM (Innocents)

Laudibus infantium EX ORE

Nate de i clemens ET LACTENTIUM

Qui tibi iam nato PROPTER INIMICOS

Int . PUER NATUS EST (Christmas)

Quod prisco vates PUER NATUS

Davitice stirpis ET FILIUS

Perdita restaurans CUIUS INiPERIUM

Int. VENITI BENEDICTI (Easter Wednesday) 0 quam felices VENITI BENEDICTI Non oculos QUOD VOBIS

COIn. PASCHA NOSTRULi (Easter) Laus honor virtus PASCHA NOSTRUM Peccata nostra CHRISTUS Len de tribu Iuda ALLELUIA

Int . CONFESSIO ET PULCHRITUDO (Laurence) Vox domino laudem CONFESSIO His celum geminis SANCTITAS

Int. GAUDEAMUS OMNES (Nativity BVM) Nativitatem GAUDEAMUS

Virginis et matris GAUDEAMUS

Et pia magnifice IN HONOREM

Ter sanctus reboant ET COLLAUDANT
Metz, Paris $909(\mathrm{~s} . \mathrm{n}$.

Metz, Prüm, St. Magloire, Autun

$"+$ other French mss.

$"+$ other French mss.

Metz, Prüm, Echternach, Kassel 15, all others non-German

Nietz, Prüm, Echternach, Kassel 15, Angelica 123

nnly St. Emmeram in East

Metz, England, St. Magloire, Nevers, Bourges, Paris 1084 and $1 / 18$

Mainz, Prüm, Echternach, Nevers, Bourges

$"$ 


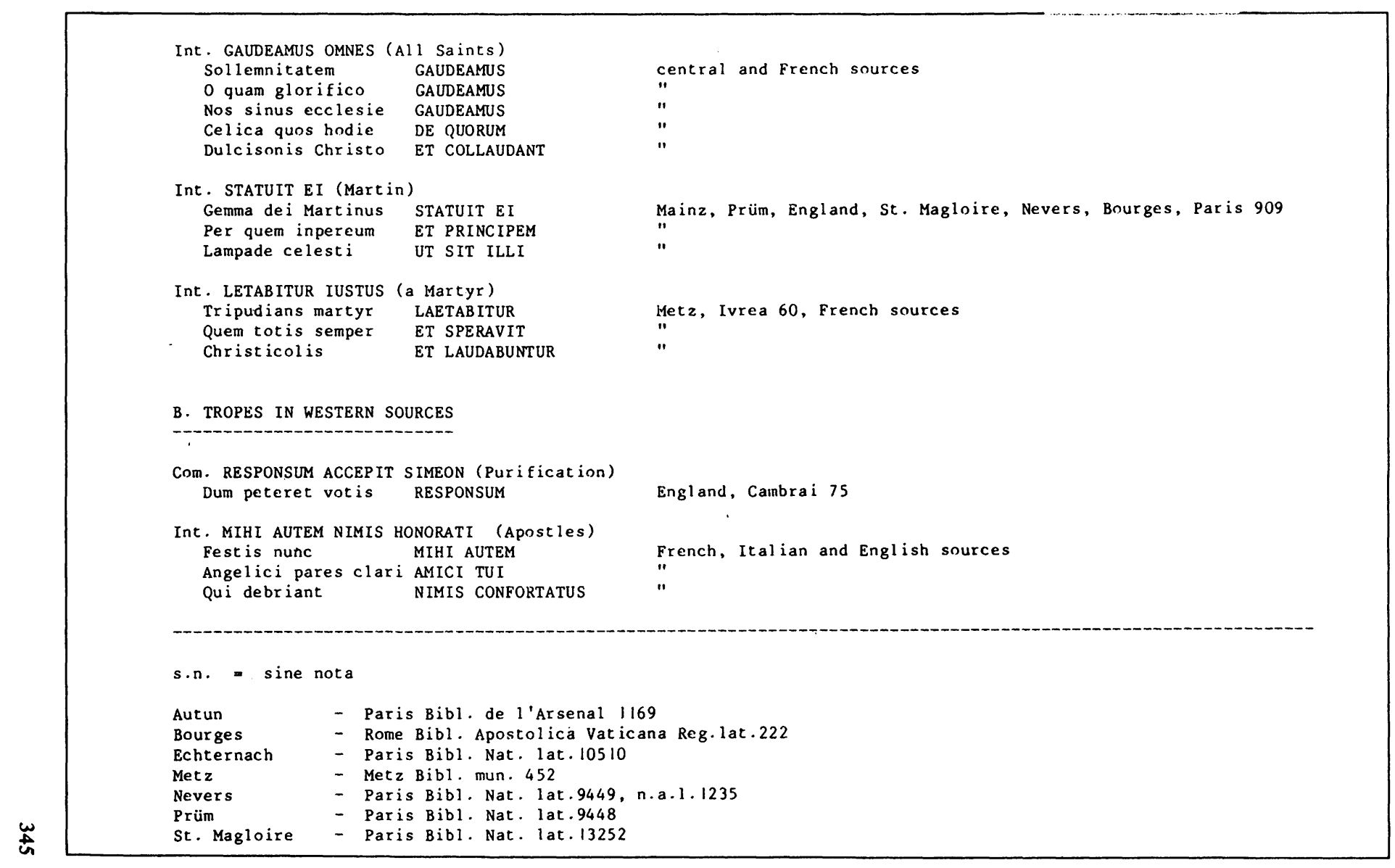




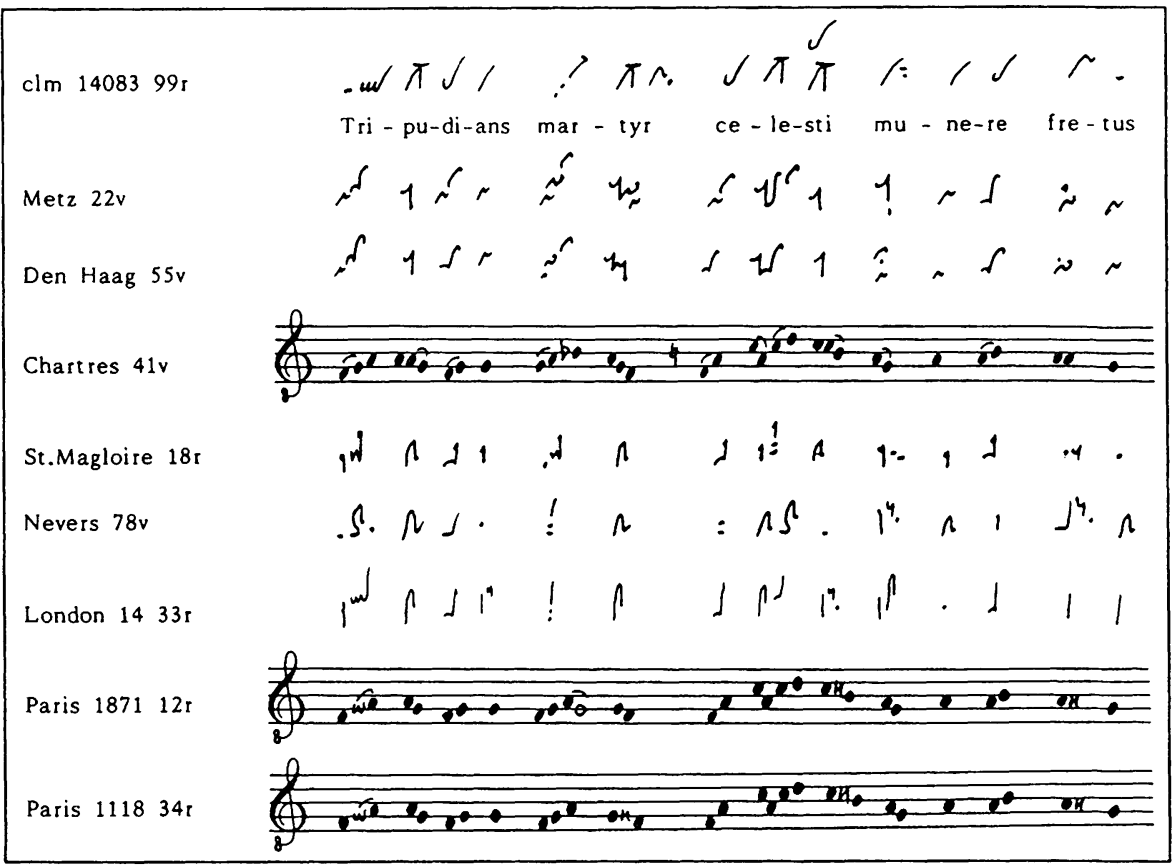

EXAMPLE 1. Trope verses for Int. Letabitur iustus

Where there is significant melodic divergence between central and western sources, St Emmeram aligns itself with the central sources. An example of this can be seen in Planchart's parallel edition of Vox domino for the St Laurence introit Confessio et pulchritudo, ${ }^{4}$ where clm 14083 and Metz 452 evidently share a common melody often diverging markedly from that in the other, western sources. Another example of this is the set Tripudians martyr for the introit Letabitur iustus (Martyrs), ${ }^{5}$ given as Ex. 1 .

There are no eastern sources apart from St Emmeram. The set survives in Metz 452 and also in another Metz source, Den Haag 10.B.12. These sources agree well over melodic details. Only in verse 1 at 'dilexit' does St Emmeram disagree substantially: it lacks the separate single note for '-xit' and redeploys the rest. The western sources are from St Magloire, Chartres, Nevers, England (London Cotton Caligula A.14) and Aquitaine. St Magloire, Nevers and London 14 share small variants against St Emmeram and Metz at (verse 1) 'martyr' and (3) 'perpes'. St Magloire has a different final phrase (3) 'glomeratus/r in evum', Nevers at (1) 'munere fretus'. London

${ }^{4}$ Alejandro Enrique Planchart, The Repertory of Tropes at Winchester, 2 vols. (Princeton, 1977), vol.I, $376 \mathrm{ff}$.

5 Planchart, op.cit., vol.II, 116. 


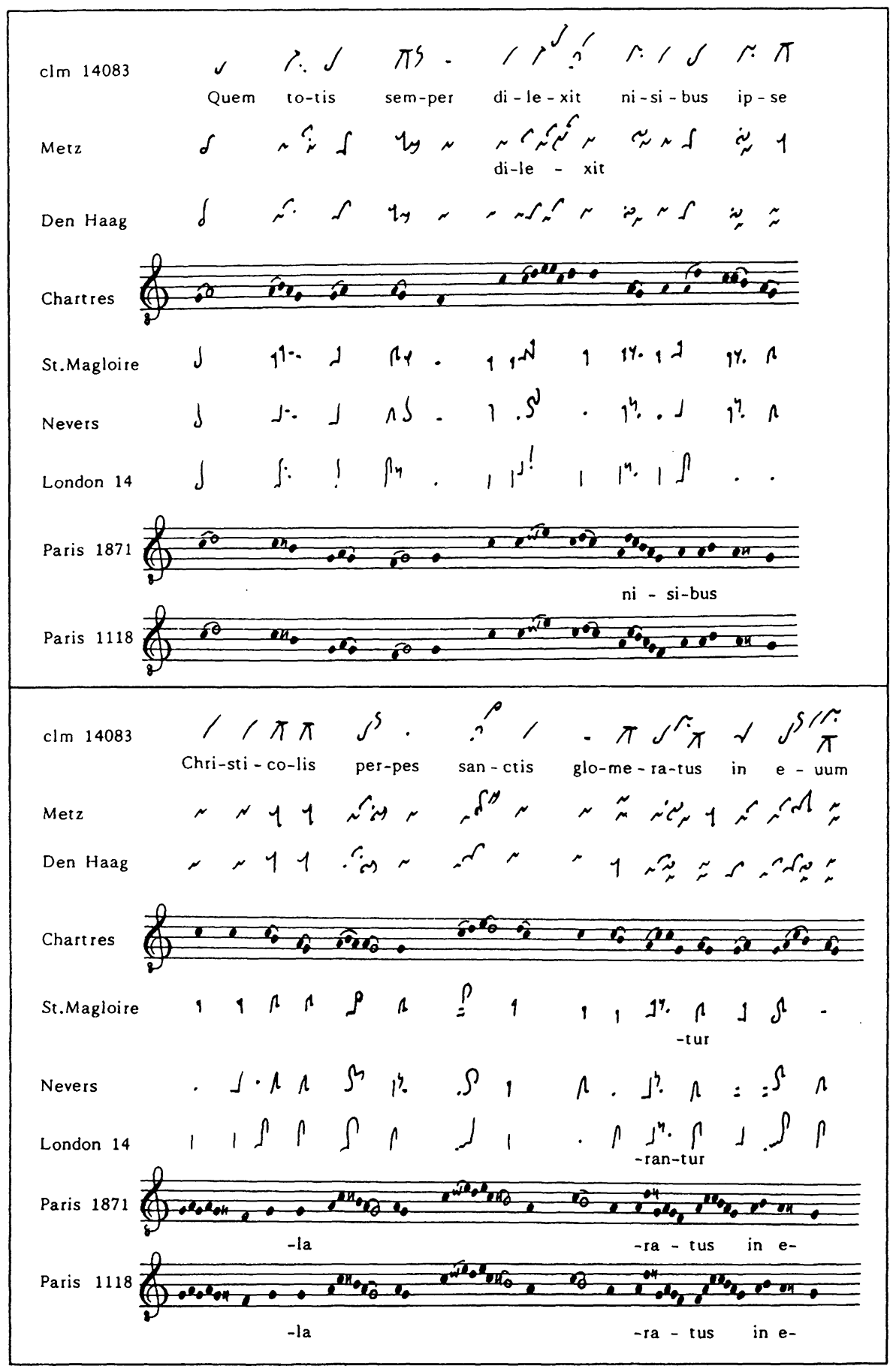

EXAMPLE 1. (cont.)

347 
14 has an extra note at (2) 'nisibus' and (3) 'Christicolis', but is somewhat closer to the central sources. Of the French sources, Chartres is perhaps the closest to St Emmeram, though there is an extra concluding note for (3) 'sanctis'. The Aquitainian versions (only two are given here) are much further removed, and could only occasionally be used to reconstruct the pitches of the sources with non-diastematic notation.

Examples like this suggest that St Emmeram was tapping sources from the Rhine/Mosel area rather than from, say, North France. That is in any case what one would expect. And the tropes which are in St Emmeram but not in those central sources tend to reinforce this impression by displaying substantial variants. Dum peteret votis is a trope verse for the communion at Purification, Responsum accepit Simeon. At two points the other sources -- the English tropers and Cambrai 75 from Arras -- agree with each other against St Emmeram: 'peteret' and 'venire/venisse', as shown in Ex.2.

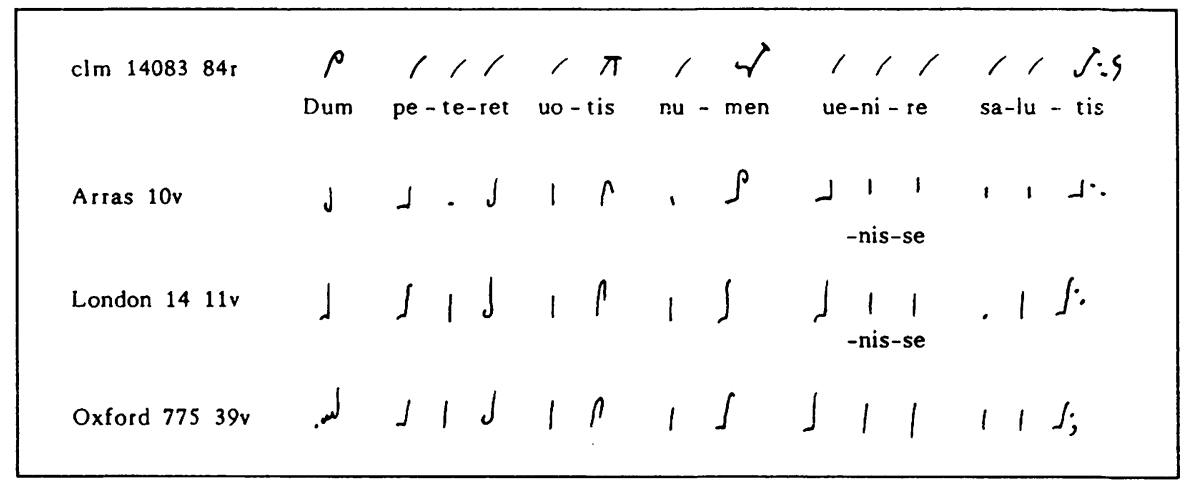

EXAMPLE 2. Trope verse for Com. Responsum accepit Simeon (Purification)

The trope set Festis nunc in apostolicis for the introit for Apostles Nimis honorati sunt provides more substantial evidence, given in Ex.3. The set appears in English books, so Planchart has already summed up the situation. ${ }^{6}$ He says that there are two main branches to the melodic tradition, the one Aquitainian, the other to be found in north Italy, Germany and England. Within the latter England goes with St Magloire, while St Emmeram and Nonantola form two separate branches. The point of this is that St Emmeram allies itself closely with no French source. And I should guess that in this and similar cases there is a gap in the surviving sources: a central intermediary which would have shown the St Emmeram version of the melody is now lost.

6 Ibid., 120. 


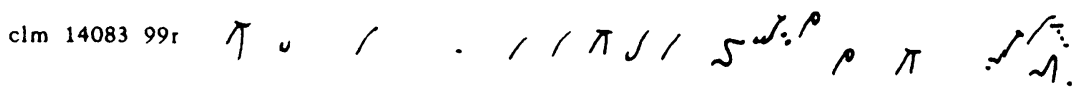
Fes-tis nunc in a-pos-to-li-cis laus clan-gat he-ri-lis

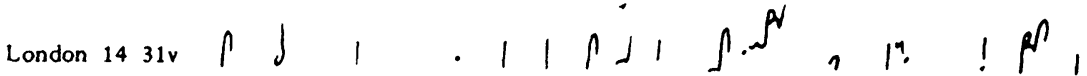

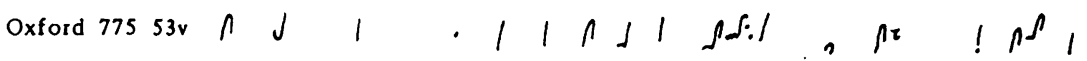

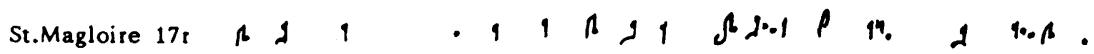

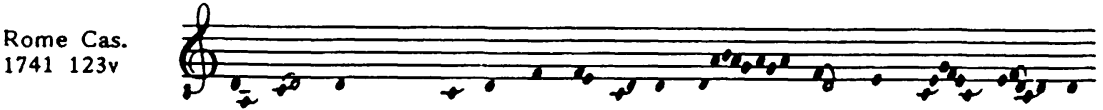

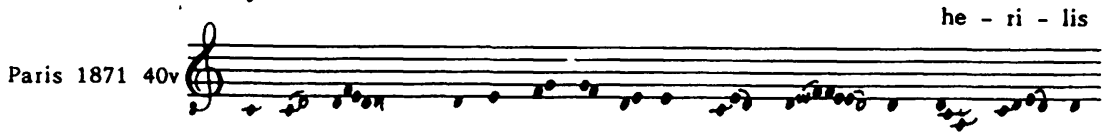

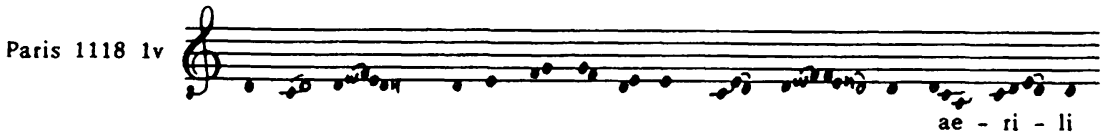

clm 14083

Oxford 775

St.Magloire

$$
\beta . / r \cdot r J / \pi / \pi \pi n \cdot
$$
An-ge-lici pa-res cla - ri su - per e-thera ci-ues

London 14 $1 \cdot|1| \underset{\text {-tres }}{1} \mid\rfloor|\rho| \rho \rho \rho 1$ $1.111 .111 \rho 1 \rho \rho \rho$. -tres 0 -ues 1741

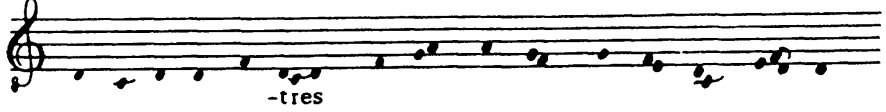

Paris 1871

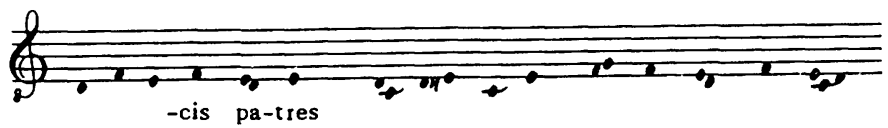

Paris 1118

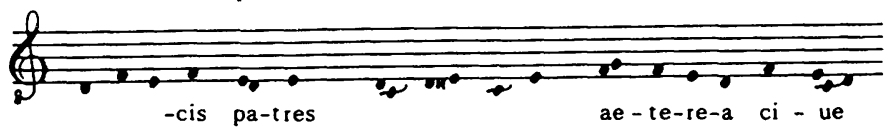

EXAMPLE 3. Trope verses for Int. Mihi autem nimis honorati (Apostles) 


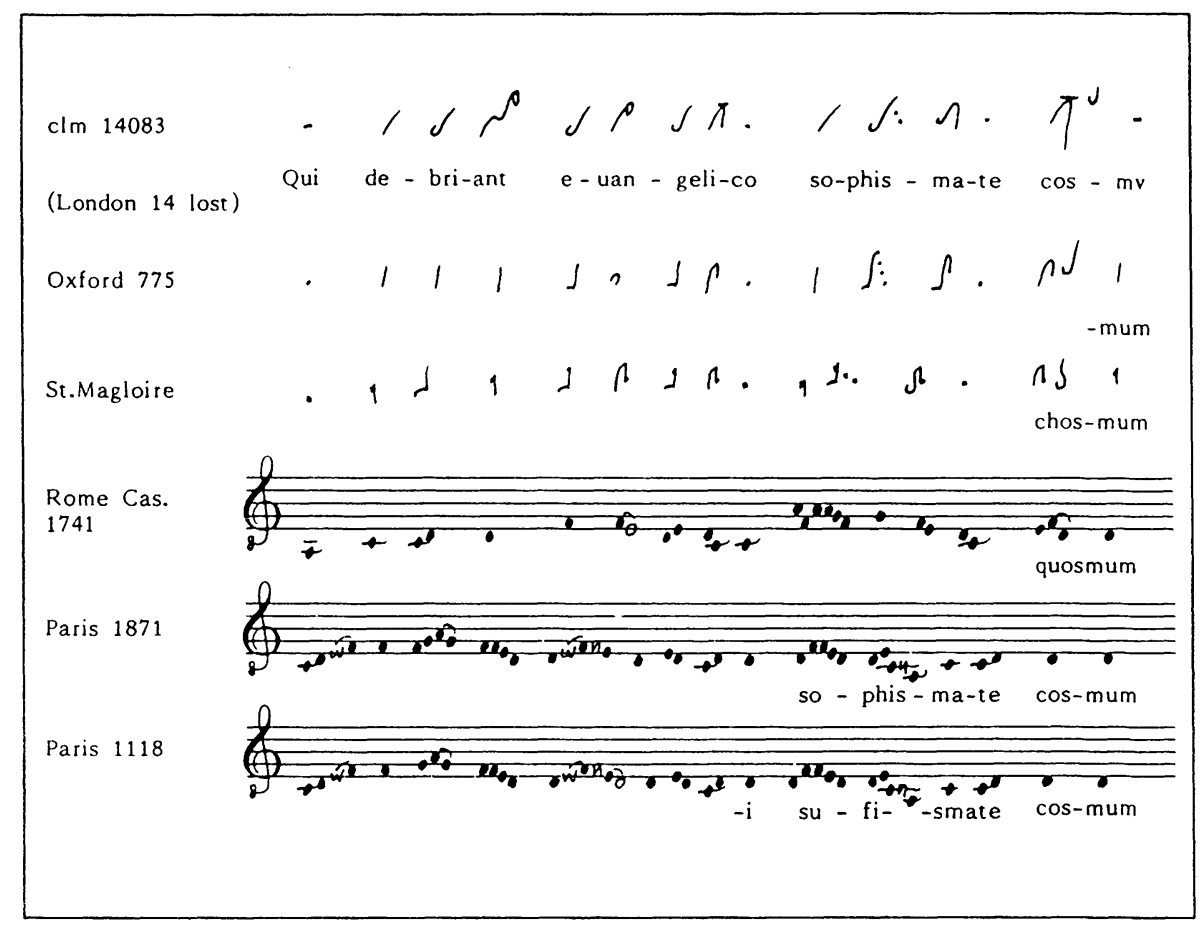

EXAMPLE 3. (cont.)

That is a hypothesis, but the evidence seems to point that way. The idea that St Emmeram was in direct contact with a French centre is by no means far-fetched, however, as we know from the manuscripts of music theory from St Emmeram. Manuscript clm 14272 is a manuscript of the early 11 th century copied principally by Hartvic of St Emmeram which contains, among other things, the Enchiriadis group of treatises and a Boethius commented by Fulbert of Chartres (1007-1029). From the second half of the century comes clm 14372, again with Musica and Scholica enchiriadis, also with three responsories by Fulbert of Chartres. Whether Hartvic actually studied in Chartres, as Bischoff suggested, cannot be proved. ${ }^{7}$ There is unfortunately little trace of contact between the trope repertories at Chartres and St Emmeram: apart from the case cited in Ex. 1 above, Provins 12, from Chartres, contains none of the unusual pieces of the St Emmeram repertory.

\footnotetext{
7 Bischoff, op.cit., Studien und Mitteilungen, 105ff; Mittelalterliche Studien, 80ff. See also Bischoff, "Hartwic von St Emmeram", Die deutsche Literatur des Mittelalters. Verfasserlexicon, ed. Karl Langosch, 5 (Nachtragband) (Berlin, 1955), 335-337. 


\section{A Kyrie trope by Otloh of St Emmeram}

Most tropes are anonymous compositions, like so much of medieval chant. A further example from the St Emmeram trope repertory enables us, exceptionally, to lift the veil of anonymity and perceive the human agent. This is not Hartvic, but Otloh of St Emmeram, whose activities have been illuminated once again by Bernhard Bischoff. ${ }^{8}$ In fact this part of my essay is somewhat in the nature of a footnote to Bischoff's work.

The piece in question is a Kyrie trope. Lack of space forbids a detailed discussion here of the make-up of the St Emmeram repertory for the ordinary of mass. As one would expect, there is a layer of old Eastern material, some compositions which seem to have originated at St Emmeram itself, and some imports from the West. ${ }^{9}$ But in the Kyrie collection are two troped items which seem to suggest an acquaintance with Italian practice: Kyrie 0 pater immense and El elion pater/Regnorum rector. (Regnorum rector is the same piece as El elion, starting however at the second verse.) Table 4 shows the position of these Kyries in the three early St Emmeram sources.

David Bjork has pointed to a number of Italian Kyries where the same melodic formula serves for Greek invocations and Latin trope verses throughout, a sort of litany. ${ }^{10}$ John Boe's work on South Italian Kyries has provided a great deal more valuable detail about this practice. ${ }^{11}$ The two Kyries just mentioned appear to be related to this type, at least at first sight.

Related but not identical. The Italian habit is to adapt the Kyrie melody somewhat freely to the Latin text, so that groups of two and three notes per syllable are sometimes present. The 'northern' practice was to apply a strictly syllabic technique, one syllable per note. The Italian, non-syllabic habit is apparently followed in

8 Bischoff, op.cit, Studien und Mitteilungen, 115-142; Mittelalterliche Studien, 88-115. See also Bischoff, "Otloh", Die deutsche Literatur des Mittelalters. Verfasserlexicon, ed. Karl Langosch, 3 (Berlin, 1943), 658-670.

9 David Bjork, "Early repertories of the Kyrie eleison", Kirchenmusikalisches Jahrbuch 63-64 (1979-80), 9-43 (see esp. pp.32-33), commenting on the large number of Kyries from outside Bavaria known at St Emmeram, argues for "a fairly direct line of transmission from the Rhineland to Regensburg sometime during the tenth or early eleventh century".

${ }^{10}$ David Bjork, "Early settings of the Kyrie eleison and the problem of genre definition", Journal of the Plainsong \& Mediaeval Music Society 3 (1980), 40-48 (see esp. pp.45-46).

11 John Boe, Ordinary chants and tropes for the Mass from Southern Italy, A.D. 1000-1250, Part 1: Kyrie eleison, Beneventanum Troporum Corpus II, 3 vols. in 2, Recent Researches in the Music of the Middle Ages and Early Renaissance XIX-XXI (Madison, 1989). See for example the Kyries listed on Table 2 in the commentary volume (XIX), xxvi-xxix, Kyries A1-3, B1-4, C1, D1-3, E1. 
KYRIE MELODIES AND TROPES

trope type

\begin{tabular}{|c|c|c|c|}
\hline \multicolumn{4}{|c|}{ BAMBERG 6} \\
\hline $89 r$ & Kyrie 57 & \multicolumn{2}{|c|}{ - added at end of sequence collection } \\
\hline & Kyrie 55 Tr. 4 & 0 theos kritis - Easter & prosula \\
\hline \multicolumn{4}{|c|}{ CLM 14083} \\
\hline $62 v$ & Kyrie $223 \operatorname{Tr} .1$ & 0 pater immense - added & (see discussion) \\
\hline $94 v$ & Kyrie $47 \mathrm{Tr}$. & $\begin{array}{l}\text { Logos patri pneumatique } \\
\text { - Pentecost }\end{array}$ & prosula \\
\hline $100 \mathrm{r}$ & Kyrie $55 \operatorname{Tr} .4$ & 0 theos kritis & prosula \\
\hline $100 \mathrm{v}$ & Kyrie $68 \operatorname{Tr} .7$ & Canamus cuncti & prosula \\
\hline $101 \mathrm{r}$ & Kyrie 68 Tr. 6 & Cunctipotens dominator & prosula \\
\hline $101 v$ & Kyrie $68 \mathrm{Tr}$ & El elion pater omnipotens & (see discussion) \\
\hline & $\begin{array}{l}\text { Kyrie } 39 \text { Tr. } 7 \\
\text { Kvrie } 39 \operatorname{Tr} 5\end{array}$ & Omnipotens genitor & $\begin{array}{l}\text { independent verses } \\
\text { prosula }\end{array}$ \\
\hline \multirow[t]{3}{*}{$102 v$} & Kyrie & \multicolumn{2}{|c|}{ Logos patri Require In Pentecosten } \\
\hline & Kyrie $36(?)$ Tr. 1 & Princeps astrigeram & independent verses \\
\hline & Kyrie $155 \mathrm{Tr}$. & Ineffabilis et interminabilis & independent verses \\
\hline $103 r$ & Kyrie $151 \mathrm{Tr}$. & Deus solus et inmensus & independent verses \\
\hline $103 v$ & Kyrie $48 \operatorname{Tr} .2$ & Kyrie sabaoht iudex & prosula \\
\hline
\end{tabular}

CLM 14322

\begin{tabular}{|c|c|c|c|}
\hline $100 \mathrm{r}$ & Kyrie $55 \operatorname{Tr} .4$ & 0 theos kritis & prosula \\
\hline $100 \mathrm{v}$ & Kyrie 39 Tr. 7 & Omnipotens genitor & independent verses \\
\hline $101 \mathrm{r}$ & Kyrie 39 Tr. 5 & Lux et origo $\ldots 0$ mundi & prosula \\
\hline $102 r$ & Kyrie 68 Tr. & Regnorum rector & (see discussion) \\
\hline & Kyrie $36(?) \operatorname{Tr} .1$ & Princeps astrigeram & independent verses \\
\hline $103 r$ & Kyrie $68 \operatorname{Tr} .7$ & Canamus cuncti & prosula \\
\hline $108 \mathrm{v}$ & Kyrie 47 Tr. & $\begin{array}{l}\text { Logos patri pneumatique } \\
\text { - Christmas }\end{array}$ & prosula \\
\hline $110 \mathrm{r}$ & Kyrie $48 \operatorname{Tr} .2$ & $\begin{array}{l}\text { Kyrie sabaoht iudex } \\
\text { - St Stephen }\end{array}$ & \\
\hline $\begin{array}{l}111 \mathrm{v} \\
112 \mathrm{r} \\
113 \mathrm{r} \\
117 \mathrm{v}\end{array}$ & $\begin{array}{l}\text { Kyrie } 24 \\
\text { Kyrie } 155 \\
\text { Kyrie } 223 \\
\text { Kyrie? }\end{array}$ & $\begin{array}{l}\text { - St John Evangelist } \\
\text { - Holy Innocents } \\
\text { - Easter } \\
\text { - Dedication }\end{array}$ & \\
\hline
\end{tabular}

[melody and trope numbers from Margaretha Landwehr-Melnicki, Das einstimmige Kyrie des lateinischen Mittelalters (Regensburg, 1955)] 
St Emmeram, but not the Italian practice of having the same melody for all verses. Kyrie 223 approaches the Italian pattern most closely:

\begin{tabular}{|c|c|c|}
\hline Kyrie 223 & 0 pater immense & $\begin{array}{l}A x A x A x \\
B x B x B x \\
C x C x C^{\prime} x\end{array}$ \\
\hline Kyrie 68 & $\begin{array}{l}\text { El elion pater omnipotens } \\
\text { Regnorum rector }\end{array}$ & $\begin{array}{l}\mathrm{AxAx} A x \\
\mathrm{Bx} B \times \mathrm{Bx} \\
\mathrm{C} C \mathrm{C}^{\prime}\end{array}$ \\
\hline
\end{tabular}

Each line ends with the same cadence (' $x$ ') but the starts are different. Kyrie 68 maintains this pattern for the first Kyries and Christes, but has a divergent third section.

Kyrie 68 was well known all over Europe, and there is no difficulty in making a transcription of the St Emmeram compositions. For Kyrie 223 only four sources with the trope verses are so far known: clm 14083, Naples Biblioteca Nazionale VI.G.34 from Troia, Madrid Biblioteca Nacional 289 from Palermo and Madrid 19421 from Catania. The melody alone appears in clm 14322. (The editors of Analecta Hymnica published the trope text from clm 14083 and Naples VI.G.34.) The opening verses of the two Kyries are transcribed in Ex.4. ${ }^{12}$

Bischoff identified the hand that copied 0 pater immense in clm 14083 - it appears as an addition apart from the other kyries - as that of Otloh, and opined that Otloh was the composer of the verses, nine Leonine hexameters. His reason for this assertion was that three of the verses (1,3 and 4) rework the first three lines of Otloh's metrical poem 0 princeps pacis, a 45 -line long prayer to the Almighty. The relevant verses run as follows.

trope:

o pater immense

cui semper idem manet esse

Sancte simul flatus

procedens non generatus

Tu princeps pacis

tu principium pietatis poem:

\section{0 patris aeterne \\ cui semper idem manet esse}

\author{
Spiritus o sancte \\ quo constant cuncta creante \\ 0 princeps pacis \\ ac principium pietatis
}

\footnotetext{
12 For Kyrie 2230 pater immense I give a transcription from the Catania source, with a suggested rendering on the stave of the neumes in clm 14083. For Kyrie 68 El elion/Regnorum rector I have simply followed what might be called a "consensus version" of Kyrie 68 and interpreted the neumes accordingly.
} 


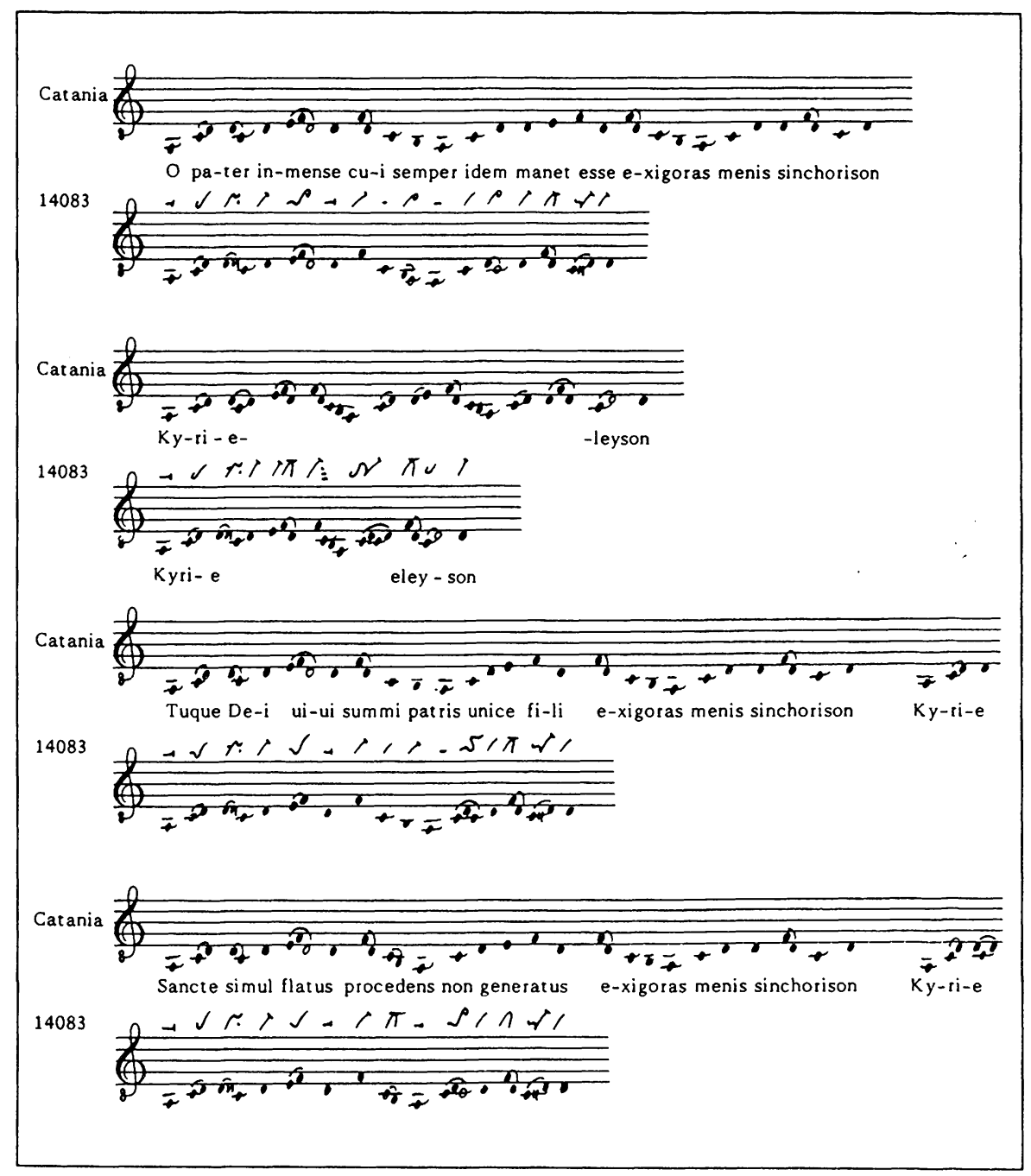

EXAMPLE 4a. Kyrie 223 O pater immense

Bischoff also drew attention to the Greek expressions in verse 7 of the trope: 'teletarchis eudochus ke kyriarchos', of which 'teletarchis' and 'kyriarchos' are apparently borrowed from the writings of Dionysius the pseudo-Areopagite. This all chimes in with Otloh's most famous (or notorious) achievement. Otloh was born about 1010 , educated at the monastery of Tegernsee, but delayed his monastic profession until after two severe illnesses (which he took as celestial reminders to fulfil former vows). He worked as a lay brother at St Emmeram before becoming a monk there in 1032. He was a friend of William of Hirsau and his name appears in William's musical and 


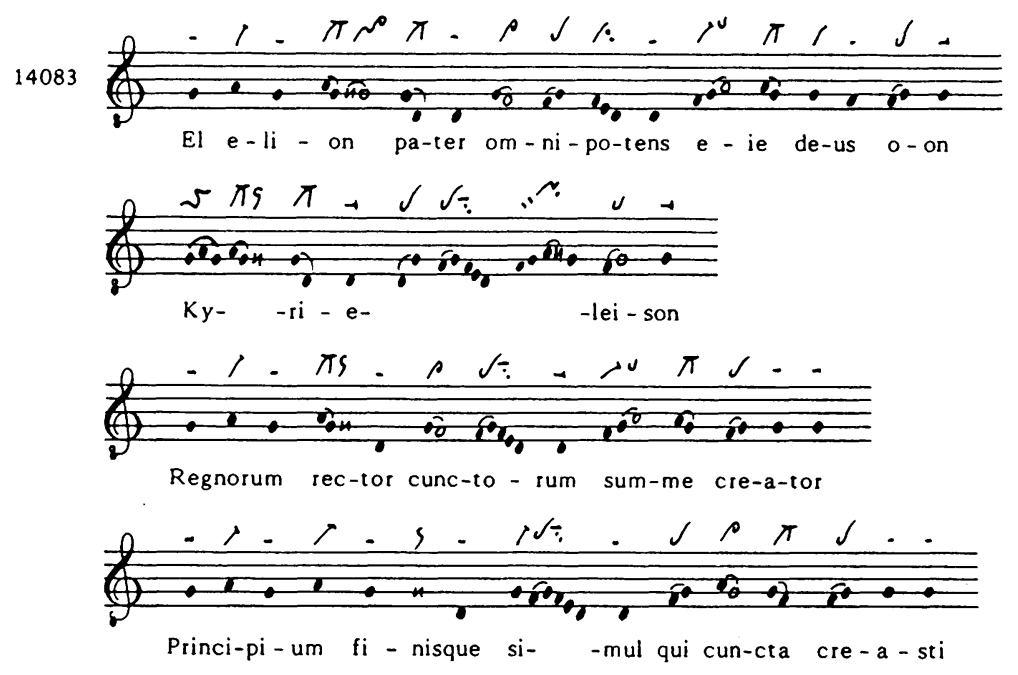

EXAMPLE 4b. Kyrie 68 El elion pater / Regnorum rector

astronomical treatises; he is known to have given William a number of missals, probably copied and illuminated by himself. He was involved in controversy about the independence of the monastery from the bishopric and had to leave St Emmeram in 1062.

As part of the campaign to assert the independence of the monastery, the monks declared in 1049 that the body of St Denis the Areopagite had been abducted by Arnulf of Carinthia from the monastery of St Denis in France and now resided in their monastery. An anonymous tract - the so-called 'Translatio $I^{\prime}$ - was produced to document the event, which on linguistic grounds Bischoff attributes to Otloh. He probably wrote a sequence in honour of St Denis and helped produce other false documents about the exemption of St Emmeram from episcopal control.

Probably at some time during these years Otloh visited Montecassino. Bischoff knew from Analecta Hymnica that the Kyrie trope $O$ pater immense was also in the Troia manuscript (he did not know of the Sicilian ones). In the southern sources it has an extra Greek verse before each of the first three Kyrie invocations, which Bischoff thinks was added. (The melody is simply repeated from the descent from c onwards.)

Now although Otloh was obviously interested in St Denis the pseudoAreopagite, the writings of the latter did not apparently influence him to any great extent. In other words, the Kyrie trope 0 pater immense, with its Dionysian element, is rather exceptional in Otloh's output. Bischoff put it like this: 'Otloh copied works of 
the pseudo-Areopagite, probably in the ambit of Montecassino; probably he composed the trope shortly after he had become acquainted with this new spiritual world, for in all the rest of his writings he betrays no influence of the Pseudo-Areopagite, either in content or in style. ${ }^{13}$

Now if Otloh composed the Kyrie trope, why should it have been copied in southern sources? Practically all the ordinary of mass chants in Naples VI.G.34 are from the Norman-Sicilian repertory, of which Madrid 289 and 19421 are prime representatives. ${ }^{14}$ Why should they contain a composition by an itinerant German monk? Is it possible that the piece originated in Montecassino, or even in Sicily, and was then simply brought by Otloh back to St Emmeram? That would explain its exceptional features when compared with Otloh's other writings. One would then have to argue that Otloh composed his prayer to the Almighty after having learned the Kyrie trope.

It is unfortunate that we have no source from Montecassino or Benevento for the composition. The Palermo manuscript dates from the mid-12th century, the Catania manuscript from slightly later, and the Troia manuscript from the late-12th or perhaps even from the 13th century. The trope can hardly be Norman, for the Normans had not even come to South Italy by the time clm 14083 was copied. But nor is it stylistically compatible with earlier Italian compositions. I gratefully acknowledge here a number of heipful suggestions made to me by John Boe, who points out ample grounds for discarding a theory of Italian origin: the melody changes between Kyrie, Christe and Kyrie, the text is in hexameters, there are Greek phrases, it is determinedly trinitarian. The melody is unlike any native Italian composition.

Which brings us back to Otloh. The appearance of the trope in Palermo and Troia is a puzzle whether or not the piece was composed by Otloh. We simply cannot bridge the gap between Otloh's time and the later southern sources. It was the textmusic relationship -- unsyllabic -- which aroused my suspicion that an Italian connection with the piece existed. But the same is also true of El elion pater omnipotens, for which only St Emmeram sources are known. On linguistic grounds Bischoff suggested that El elion pater omnipotens might come from the circle of prior Arnold, a slightly older contemporary of Otloh, who on a journey to Hungary composed antiphons and responsories for the office of St Emmeram for Bishop John of Esztergom (Gran). ${ }^{15}$ All this tips the balance in favour of Bischoff's hypothesis. We

\footnotetext{
13 Bischoff in Studien und Mitteilungen, 123; Mittelalterliche Studien, 97.

14 David Hiley, "Quanto c'è di normanno nei tropari sicilo-normanni?", Rivista Italiana di Musicologia 18 (1983), 3-28. At that time, knowing nothing of Otloh, I classified $O$ pater excelse as "probably Sicilian"! Compare the lists for these manuscripts in David Hiley, "Ordinary of mass chants in English, North French and Sicilian manuscripts", Journal of the Plainsong \& Mediaeval Music Society 9 (1986), 1-128.

15 Bischoff in Studien und Mitteilungen, $110 \mathrm{ff} ;$ Mittelalterliche Studien, $85 \mathrm{ff}$.
} 
would then have two Kyrie tropes with a unique text-music relationship, perhaps influenced by Italian practice, one with a text also inspired by contact with Italy. It is worth remembering that the technique of composing Kyrie tropes favoured in early German centres had the music of the trope verses quite independent of the Kyrie melody. As with all trope verses of this type (for the Gloria, or the proper chants of the mass, for example), a syllabic musical setting was not usual. Perhaps, therefore, for his new trope verses Otloh was adapting Kyrie melodies he knew (not such a common procedure in his home area) but falling back on the type of setting (that is, non-syllabic) to which he was accustomed. 16

Even if some aspects of these Kyries remain puzzling, it may fairly be claimed that musical analysis adds a valuable dimension to their investigation. And it is rarely that so many factors -- ecclesiastical-political, cultural-historical, theological and philological -- impinge upon musical items such as these. The case of Otloh of St Emmeram cannot have been unique. The fact that a known personage, and a rather remarkable one at that, was involved adds human interest to the investigation, but the same questions can asked, the same avenues of inquiry followed, for pieces that remain anonymous. The analysis of transmission patterns and of literary and musical style is the key which enables us to unlock the doors of this repertory, as of others.

16 Another stylistically somewhat ambivalent item in the St Emmeram Kyrie repertory, Princeps astrigeram, has been discussed by Bjork, "Early repertories", 33. 